\title{
Original Undergraduate Research in Classroom Contexts: Student Perceptions of a Scaffolded Approach
}

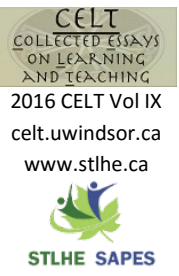

\author{
Karen Manarin, April McGrath, and Miriam Carey \\ Mount Royal University
}

This article describes a model for supporting undergraduate research that can be adapted for very different classroom contexts; we implemented this model in a first-year general education composition class, a second-year Psychology class and a fourth-year English literature seminar. We examine student work created for each class as well as reflections and interviews to explore student attitudes towards and perceptions of research. While the scaffolded approach had an impact on students' understanding of the research process, the effects did not vary significantly by level and context as we had expected.

\section{Introduction}

U Jndergraduate research is a high-impact educational practice that leads to gains in critical thinking skills, information literacy, and communication skills (Kuh, 2008; Lopatto, 2010). These gains are particularly significant for students from under-served populations and for highachieving students (Brownell \& Swaner, 2010; Taraban \& Logue, 2012). Some have made the ideological claim that if undergraduate research leads to learning gains, it should be available to all students at multiple points during their studies (Healey \& Jenkins, 2009).

This project examined research projects embedded within regular undergraduate classes. In what follows, we describe a model that can be adapted for very different classroom contexts; we implemented this model in a first-year general education composition class, a second-year psychology class, and a fourth-year English literature seminar. We were interested in the following research questions: What do students identify as the purposes and challenges of research in an undergraduate context? Does a scaffolded approach to original undergraduate research impact students' under- standing of the research process? Do these perceptions and this impact vary with level and context? We look at student work created for the class, as well as student reflections and interviews. We summarize student attitudes to undergraduate research before and after experiencing the model. First, however, we situate this model within the research literature around undergraduate research and describe the undergraduate research scaffold.

\section{Background}

The Council on Undergraduate Research (2011) defines undergraduate research as "An inquiry or investigation conducted by an undergraduate student that makes an original intellectual or creative contribution to the discipline." This definition allows for multiple forms of undergraduate research experiences across disciplines; however, it insists upon originality and focuses on a product. Others have argued that it is more accurate to describe undergraduate research as a series of activities along a continuum or continua. Healey and Jenkins (2009) situate activities on two axes: student role (from audience to participant) and focus (from product to process), leading to a four-quadrant model, while 
Willison and O'Regan (2007) identify two key variables: degree of known-ness and degree of student autonomy. The Research Skills Development Framework (2007) out of the University of Adelaide identifies different facets of research across levels based upon the amount of scaffolding provided to the student. These tools can be used to design different types of undergraduate research experiences, including those within a classroom.

Much research into undergraduate research focuses on the co-curricular activities of highachieving students engaged in mentored relationships with faculty (Kardash, 2000; Lopatto, 2004; Hunter, Laursen, \& Seymour, 2007; Russell, Hancock, \& McCullough, 2007). Research into undergraduate research experiences often relies upon self-report surveys (Kardash, 2000) or surveys of faculty members (Landrum \& Nelsen 2002). Linn, Palmer, Baranger, Gerard, and Stone (2015) argue for studies that move beyond surveys to encourage students to identify initial ideas and reflect upon experiences.

There has been greater attention to coursebased undergraduate research in the last decade (Shanahan, Ackley-Holbrook, Hall, Stewart, \& Walkington, 2015) although Taraban and Logue (2012) argue against the "unconstrained pedagogical model" of undergraduate research for all students; they call for "practices and mechanisms to assure that these students [average and below average ability] benefit more fully from academic opportunities, including research participation” (p. 521).

This study, then, contributes to the research literature by exploring course-based undergraduate research experiences through student reflection. We seek to develop practices that will help students of multiple abilities benefit from research participation. We explore the use of a research scaffold within three different classes. The scaffold was developed with reference to the work of Healey and Jenkins (2009), Willison and O'Regan (2007), and the Research Skills Development Framework (2007). Healey and Jenkins (2009) offer multiple case studies of undergraduate research embedded within different levels of the curricula. Willison and O'Regan (2007) and the Research Skills Development Framework (2007) break down the research process into particular facets: identifying a need for information, finding or generating information, evaluating information, organizing information, synthesizing and analysing information, and communicating information. These stages have similarities to Kuhlthau's (2004) information search process: initiation, selection, exploration, formulation, collection, and presentation. We used these frameworks to create an undergraduate research scaffold.

\section{The Undergraduate Research Scaffold}

The research scaffold included the following elements: a research log handed in over the course of a term, a poster presentation, and a research paper. It was not the only assignment in each course; however, in each case, we adjusted the curriculum to allow space and time for it. For example, in the English seminar, using the scaffold meant leaving out one novel and one student essay because there had to be time during the term for the students to learn about and engage in original undergraduate research.

The research $\log$ involved the following entries (250-500 words each):

1. Finding an Area of Inquiry: Scan the literature to look for an area where you can make a contribution. Why you? What knowledge or skills can you bring to this inquiry? Where will you look during a literature review?

2. Identifying a Theoretical Frame: How are you going to look at the material? Are you interested in a particular approach? What tools do you need to answer your question? Have other people used these tools?

3. Conducting a Literature Review: Who has said what? Is there anything left for you to say? Can you identify a gap or deficiency in the research? Who or what could help you? Why should your piece be written? What could it contribute? Do you have a research question?

4. Integrating Claim and Evidence: What is your claim? What connections do you need to make your argument? What evidence do you need to make your argument? 
5. Incorporating Feedback: After the poster session, what changes did you need to make to your argument? Did people raise questions or objections that you hadn't considered? Did they ask for more explanation?

The first research log was due within the first few weeks of the 13 week term; the fifth research log came in with the final paper at the end of term. Each log provided an opportunity for the instructor to provide quick feedback on the research process and to redirect if necessary. A number of students wanted to switch topics around week eight, as they experienced frustration with the research process; however, if it was a big change, they had to do the research logs again, so very few students changed their topics dramatically. More often, as they worked through the different logs, you could observe the research project shifting as they found and failed to find information they needed.

Between the fourth and fifth research logs, students participated in poster sessions roughly two weeks before the research papers were due. Thus, we were able to frame research as a process of knowledge creation that should be presented publicly for peer review and critique. For the poster sessions, each class was divided into two: one group put up posters around the class while the other group circulated, asking questions and offering feedback; the next class, the roles were reversed. For many students, this poster presentation seemed to be the key moment of dissemination. They had developed their topics based on their interests, their work was on display for their peers, and they knew more than anyone else there about that particular artifact or data set. The fifth research log explicitly asked students to reflect upon peer feedback at a time when they were writing their final paper. They did not have to incorporate this feedback, but they needed to articulate its relationship to their work.

In each of these three courses, then, students were engaged in knowledge creation with their own data or unique objects of study through a scaffolded process. Even at the first and second-year level, we had students working with original material because we wanted students to experience a more authentic research experience, rather than default to repeating someone else's research.

For the first-year composition class, Writing about Images, students had to select an image that had not been written about before. Many chose images that had personal significance for them; sometimes students had created the image. Students then researched what other people had said about that type of image or what was represented in the image, before deciding whether these larger frameworks of knowledge fit the particular image they were writing about. For the second-year psychology class in research methods, students had to design a research project involving a Likert-scale survey, go through a modified institutional review process, conduct a literature review, collect and analyse data, and present their findings. Many students chose to focus on topics like stress in university. The fourth-year English seminar focused on eighteenth-century gothic literature, so students had to research and write about either a lesser-known novel of the time period (available through online databases), or a contemporary phenomenon that they could link back to the gothic tradition. Their challenge was to create something that could be presented at a disciplinary conference, and indeed, a couple students have gone on to present at conferences. More importantly, all of the students have experienced the research process. The research topics and final products differed for each class according to disciplinary expectations and level, but we all used the same scaffold to foreground the process of research.

\section{Researching Undergraduate Research in Classroom Contexts}

In Fall 2013, we, the instructors of a first-year writing class, a second-year psychology research methods class, and a fourth-year English seminar, gathered data about the undergraduate research process in these courses. This study was approved by our institution's Human Research Ethics Board. All students completed the research scaffold as part of their regular coursework; however, we did not know until after the courses ended who allowed us to examine their written work for this research study: 
17/32 writing students, 14/27 psychology students, and 10/24 English students. We also conducted semi-structured interviews with two writing students, three psychology students, and four English students after the courses were over.

\section{What Do Students Identify as the Purposes and Challenges of Research in an Undergraduate Context? Do These Perceptions Vary by Level and Context?}

To address the first of our research questions, we looked at open-ended responses to a series of questions we posed during the first week of class. We asked our students to write about why instructors assigned research projects. We also asked them to write about the hardest and easiest parts of research. Reading through the responses during the term allowed us to start addressing common perceptions about, and attitudes towards, research as we introduced the scaffold and talked about research as knowledge creation intended for an audience.

In response to the question "Why do instructors assign research projects?" students in all three courses identified developing knowledge and skills as the primary reasons. As a student in the firstyear writing class put it, "Effective research is an acquired skill that requires practice. I have not done much research myself, but the university environment provides the means to learn.” A fourth-year student expanded on this theme:

I suppose that professors assign research to facilitate critical thinking and to help their students learn how to gather, analyze, and incorporate information in to their understanding of a subject. Also research requires active learning rather than passively listening or reading information, which therefore helps to create both a better learning strategy and a deeper sense of knowledge about whatever it is that is being taught.

This quotation could come straight from the literature promoting undergraduate research experiences. And indeed most students recognized the potential benefits of undergraduate research. However, students also indicated that the instructor has motivations beyond student learning. Students in the second and fourth-year courses identified assessment as a key element; instructors assign research so that they can differentiate between students. Some students in the first-year course suggested a different motivation: instructors assign "research papers and other pieces of dreadful work" because they want to see students suffer. Other students in the first-year course indicated that they just didn't know why instructors assigned research projects. Sometimes, disciplinary expectations may have had an influence. For example, psychology students talked about preparation for graduate school, while English students talked about research in terms of moral or intellectual development, an often implicit justification for the study of literature.

When asked what they expected the hardest part of the research project to be, students in all three classes wrote about understanding information, though again the terms they used were sometimes specific to their discipline. For example, the psychology students talked about analyzing data while the English students talked about making connections between texts. Both psychology and English students worried about narrowing down the question, while students in the first-year writing class worried about finding "good" information and citing correctly. Here we see traces of a significant shift in understanding what research involves between students new to the university and more senior students. Students in the first-year class were very anxious about correct format. Certainly citation is important for research; however, there is little evidence that they understood the function of citation beyond it being an arcane requirement. When asked what they expected the easiest part of the research project to be, students talked about finding information, even in the first-year class where finding "good" information was identified as difficult. Students coming into university expect that they will need to use different types of sources; whether these expectations are confirmed is a different, and perhaps more interesting, issue. 
Does a Scaffolded Approach to Original Undergraduate Research Impact Students' Understanding of the Research Process? Does this Impact Vary with Level and Context?

To explore these questions, we looked through the research logs and other class work for comments about the scaffolded process; we also examined the nine semi-structured interview transcripts. There, we asked participants to talk about the research process they had experienced in this class and whether it was similar to what they had done previously. The scaffolded approach appears to have had a significant impact on those who were interviewed; however, similar themes emerge regardless of level. Students from first to fourth year, from a required general education course to a senior seminar designed for majors, identified four themes: that the project was different from a typical paper; that it took more time and effort; that the scaffold was important because it broke the research process into steps; and that they felt a greater level of engagement, autonomy, and accomplishment. Often, multiple themes appear within the same quotation. For example, a student in Writing about Images addressed the novelty of, amount of effort required by, and pride of accomplishment in the undergraduate research experience:

So I guess I didn't expect to develop... I think it was a learning process and I think I surprised myself by being able to pull this off by the end of this semester. And being like "wow this is really what it takes" and it's not just looking through Google finding whatever you can find. It's really about spending the time doing it. And I think that is really what surprised me the most.

What surprises us the most about this statement, from a student in a first-year class, is the student's expectation going in to the project that he or she won't develop or learn. Certainly many of the students in Writing about Images were extremely proud of what they were able to accomplish, but also surprised by how much work it took. It wasn't what they expected.
This sentiment was shared by the secondyear psychology students. One student described the difference developing a topic made and the importance of the scaffold's support:

Most of the time ...you're just doing what you are told to do. Whereas this is like you are given so much freedom, that was true researching. [but] it could have gone so south like if it was taught in a different way or if we would have just been given this and given the freedom without this, without the steps I guess.

[Most surprising thing?] Definitely how long it took.

Another student from the same course said:

I was just so like unfamiliar with the process of researching but I guess I would say the research logs actually really did help a lot... This was just way more intensive I would say. Because it was based on a question I came up with on my own and not like a question provided by a professor or about a book or something.

They were surprised when they first saw that the research logs were spread over the term; they weren't sure how a research project could take so long. They were motivated because they were interested and felt some ownership towards the project, unlike most of the papers they churn out.

Thus far, we've been discussing first and second-year courses; we expected a more nuanced understanding of research from the fourth-year English students. After all, they have had multiple opportunities throughout their degree to write research papers, although, with one exception discussed below, these senior-level students had not experienced a scaffolded approach to undergraduate research. Yet the same themes emerge:

I think this was only the second time I've actually taken a book out of the library and used it for part of my research and actually done more in terms of getting sources than what was required. [why?] I think because it was something that I was interested in...It was something I was really wanting to figure out more about, and it was mine. [most surprising] how much I had done ahead of 
time, before I actually had started writing my paper.

Three of the four students interviewed from the English seminar described this research experience as significantly different from anything they had done previously. Typically, they select a topic from a list provided by the instructor and rehearse what other people have said. They usually research while writing the paper as they find what they need to support a particular thesis. The fourth student had experienced a different version of the scaffold in a previous course a couple years earlier. She said:

maybe that's why I do my research that way now [laugh] is because that was the first class I had to do research and use a research process. But yeah, I do find that when I work on a project I tend to read everything and then when I read that, and feel like I've read enough and start to get interested in a specific area then I'll start to read in that area of inquiry and begin to narrow it and narrow it and narrow it.

This pattern of behavior is probably closer to what faculty hope most students will do. However, if we want students to experience undergraduate research as more than google-trawling for sentences that fit a predetermined thesis, we need to emphasize more than the final product of research. That is, we need to focus on key steps in the research process.

There were very positive reactions to the scaffold among students who were interviewed. But what about those who weren't interviewed? What about the content that had to be left out of the courses because of the scaffold? And with all this emphasis on process, what about the research products, those final papers at the end?

Our research continues as we examine the sources cited in the research papers, looking, not for plagiarism, but for how these students have integrated their projects within an existing knowledge base. We recognize that, for many, this was their first and perhaps only experience of original undergraduate research, but at least they did it once. To get better at it, they have to do it more than once.

Anecdotally, we can say that the class reaction varied between the courses, from general enthusiasm in the first-year course to a certain amount of resentment at the fourth-year. Some of the interviewees talked about their classmates' resistance there. After all, many students have already learned a research repertoire that generates good grades. Why would they want to expose themselves to the frustration and uncertainty of real research, especially in the confines of a thirteen-week course? Is the fourth year the right time to introduce undergraduate research, or is it simply too late? If undergraduate research processes beyond citation format were introduced in the first year, and particular skills and habits developed in the second and third years, imagine what could be possible in the more specialized courses.

\section{References}

Brownell, J. E., \& Swaner, L. E. (2010). Five high impact practices: Research on learning outcomes, completion, and quality. Washington, DC: Association of American Colleges and Universities.

Council on Undergraduate Research. (2011). VIEW ITEM

Healey, M., \& Jenkins, A. (2009). Developing undergraduate research and inquiry. York: Higher Education Academy.

Hunter, A., Laursen, S., \& Seymour, E. (2007). Becoming a scientist: The role of undergraduate research in students' cognitive, personal, and professional development. Science Education, 91, 36-74. VIEW ITEM

Kardash, C. M. (2000). Evaluation of an undergraduate research experience: Perceptions of undergraduate interns and their faculty mentors. Journal of Educational Psychology, 92, 191-201. VIEW ITEM

Kuh, G. (2008). High impact educational practices: What they are, who has access to them, and why they matter. Washington, DC: AAC\&U. 
Kuhlthau, C. C. (2004). Seeking meaning: A process approach to library and information services $\left(2^{\text {nd }}\right.$ ed.). Westport, CT: Libraries Unlimited.

Landrum, R. E., \& Nelsen, L. R. (2002). The undergraduate research assistantship: An analysis of the benefits. Teaching of Psychology, 29, 15-19. VIEW ITEM

Linn, M. C., Palmer, E., Baranger, A., Gerard, E., \& Stone, E. (2015). Undergraduate research experiences: Impact and opportunities. Science, 347, 627-633. VIEW ITEM

Lopatto, D. (2004). Survey of undergraduate research experiences (SURE): First findings. Cell Biology Education, 3, 270-277. VIEW ITEM

Lopatto, D. (2010). Undergraduate research as a high-impact student experience. Peer Review, 12(2), 27-30.

Research Skills Development Framework. (2007). University of Adelaide. VIEW ITEM

Russell, S. H., Hancock, M. P., \& McCullough, J. (2007). Benefits of undergraduate research experiences. Science, 316, 548-549. VIEW ITEM

Shanahan, J. O., Ackley-Holbrook, E., Hall, E., Stewart, K., \& Walkington, H. (2015). Ten salient practices of undergraduate research mentors: A review of the literature. Mentoring \& Tutoring: Partnership in Learning. VIEW ITEM

Taraban, R., \& Logue, E. (2012). Academic factors that affect undergraduate research experiences. Journal of Educational Psychology, 104, 499-514. VIEW ITEM

Willison, J., \& O’Regan, K. (2007). Commonly known, commonly not known, totally unknown: A framework for students becoming researchers. Higher Education
Research and Development, 26, 393-409. VIEW ITEM

\section{Acknowledgements}

We would like to thank the Mount Royal Institute for Scholarship of Teaching and Learning for supporting this research with a TransCanada Collaborative SoTL Inquiry Grant.

\section{Biographies}

Miriam Carey, Ph.D. is an Associate Professor of Policy Studies at Mount Royal University; she teaches in general education, political science, and policy studies. She is interested in student engagement and leadership and is one of the co-authors of Critical Reading in Higher Education: Academic Goals and Social Engagement (2015).

Karen Manarin, Ph.D. is Professor of English and General Education at Mount Royal University. With Miriam Carey, Melanie Rathburn, and Glen Ryland, she recently published Critical Reading in Higher Education: Academic Goals and Social Engagement through Indiana University Press.

April McGrath, Ph.D. is an Assistant Professor in the Department of Psychology at Mount Royal University with a background in social psychology. Her work in SoTL focuses on communication breakdowns between students and instructors about writing through the feedback and revision process. She also has an interest in developing practices to help students overcome statistics anxiety in order to improve their mastery of the topic. Her articles have been published in the Canadian Journal for the Scholarship of Teaching and Learning, the International Journal for the Scholarship of Teaching and Learning, and Teaching of Psychology. 
